\title{
INNOVATION DEVELOPMENT OF THE FURNITURE INDUSTRY IN BULGARIA Radostina Popova ${ }^{1}$
}

Abstract: This paper presents an analysis of the innovation performance of furniture enterprises in Bulgaria for two periods before the economic crisis and after it. It contains general characteristics of the Furniture industry (structure of the enterprises, different type of production, export and import) and the results of the surveys of the innovation activity for two 3 year periods. The results from the studies are of the periods: 2006-2008 (563 enterprises) and 2014-2016 (358 enterprises) and are based on officially used EU definitions and indicators (European Commission, OECD, Oslo Manual), which allows for comparability of results. The used indicators are: introduced product innovations, introduced process innovations, introduced organizational innovations, introduced marketing innovations, revenues and costs of innovation and financing of the innovation activities.

The results of the comparative analyses of the innovation activity of the furniture enterprises in Bulgaria for the two periods under review showed an increase in: the innovation expenditures and revenues from innovative products, the process innovations - additional activities and the financing of innovation activities by the EU. It also showed a decrease in the number of furniture enterprises, product innovations, process innovations and organizational innovations.

JEL Classification Numbers: 031, O32, L73, DOI: 10.12955/cbup.v7.1370

Keywords: Innovations; R\&D; Furniture; Revenues; Expenditures

\section{Introduction}

The Forestry Industry in Bulgaria had a dynamic development and showed an increasing numbers of enterprises and employees up until 2008. After the financial crisis, this trend was interrupted till 2013 when the sector started to bounce back. The industry has a tradition of furniture production, raw material availability and export potential. In addition, the strengthening of competition, including by Asian manufacturers, puts the production of furniture in Bulgaria in check and puts into focus its innovation activities and innovation development.

The main goal of this article is to present an analysis of the innovation performance of the furniture enterprises in Bulgaria for two periods - before the economic crisis and after it.

\section{General characteristic of the Furniture industry in Bulgaria}

There are about 2000 furniture enterprises in Bulgaria consisting of micro, small, medium-sized and large enterprises. They produce EUR 965.2 million and generate $12.1 \%$ of European furniture. According to the statistical data, more than $99 \%$ of the companies from the Furniture Industry in Bulgaria are micro, small and medium sized enterprises $-80 \%$ of them are micro enterprises. The largest furniture enterprises in Bulgaria are: "Mebel Still" - Targovishte (650 employee); "Sredna Gora" - Stara Zagora (500 employees); "Paralell" - Sevlievo (285 employees) (Eurostat, BCWFI, 2018).

Furniture enterprises, depending on the objects, produce furniture for public spaces (hotel furniture, office furniture, school furniture, etc.) and home furnishings (kitchens, bedrooms, dining rooms and living rooms) in the form of sofas, tables, chairs and furniture parts. This diversity suggests variability and flexibility of complete solutions and new products often require new technologies, techniques and working methods.

The products manufactured in furniture enterprises are extremely diverse (styles and models, colors and sizes) and hence employ a variety of forms of organization of production, depending on the type of production - small businesses with a single type of production and tailor made work are individual form organization, while group form of organization has an increasing specialization of production operations, equipment and production volumes. It reflects design development, engineering and technology, and the training of staff.

The main countries for export and import of the furniture enterprises in Bulgaria are: (BCWFI, 2018)

- Export: Germany; Italy; France; Czech Republic; Great Britain;

- Import: Germany; France; Italy; Poland; Spain.

\section{Methodology}

Basic definitions

In the literature there are different definitions of innovation, which is associated with novelty. Novelty (lat. Novation - amendment, renewal) is something that has not existed until now - a new order, a

\footnotetext{
${ }^{1}$ University of Forestry, Sofia, Bulgaria, radost.k.popova@abv.bg
} 
custom method invention phenomenon. Innovation as a result of investment activity is in fact a materialized result obtained on the capital invested in new technology, equipment, forms of organization of production and human resources administration and management, new methods of planning and analysis, new forms of reporting and more. (Gault, 2018)

According to Oslo Manual $(2005,2018)$ an innovation is a new or improved product or process (or combination thereof) that differs significantly from the unit's previous products or processes and that has been made available to potential users or brought into use by the unit.

Officially accepted and used in the EU classification, business innovation is divided into 4 types of innovations that can be made in an enterprise. (Oslo Manual, 2005)

Product innovations are the realization of a product or service that are new or significantly improved in terms of their capabilities, ease of use by the consumer, components and subsystems.

Process innovations are related to the introduction of new or significantly improved, manufacturing processes, delivery methods and support activities (accounting, computer, etc.).

Organizational innovations are new ways of organizing work and relationships with other companies and organizations that have not previously been used, and new business practices.

Marketing innovations are implementing new marketing research, marketing database, marketing concepts and strategies that have not been used before and are significantly different from existing enterprise marketing tools.

Indicators

Unrepresentative studies and partial interpretations of the innovation in the Forestry industry in Bulgaria are made by international projects and programs (COST, INNOFORCE - EFI, INTRRREG,etc.), projects of the University of Forestry.

Representative surveys on the issue in the forestry industry in Bulgaria were for the first time made in the period 2006-2012 (Popova, 2013).

The European methodology of the European Commission for the relevant period was used. The survey of innovation activity of enterprises in the EU is done every three years, according to the methodological guidelines of the Oslo Management for Corporate Innovation Assessment. During the different periods of study, the focus of the questionnaire is different - eco-innovation, competitiveness, innovation in logistics. But the main indicators, which remain unchanged and allow comparability and comparability, and which are also used in this study are the following:

Revenues and expenditures related to innovation

The innovation activity is carried out in enterprises over a 3-year period. Specific innovation activities that make expenditures in this area are:

- R \& D carried out in the enterprise;

- R \& D provided by another enterprise;

- Acquisition of equipment and software related to innovation;

- Acquisition of external knowledge related to the development of product and process innovation;

- Training related to innovation;

- Marketing activities presenting the innovation;

- Technical and preparatory procedures for the production of new or improved products and introduction of new or improved processes.

Introduced product innovations

Product innovations are the realization of a product or service that is new or significantly improved in terms of its capabilities, ease of use by the consumer, components and subsystems. This means changes in terms of its characteristics, purpose, use, software, components, materials, subsystems, technical specifications and other functional characteristics.

Introduced process innovations

Process innovations are related to the introduction of new or significantly improved, manufacturing processes, delivery methods and support activities (accounting, computer, etc.). This includes significant changes in techniques, equipment and / or software. They can be designed to reduce the 
unit costs of production or delivery, improve quality, production or delivery of new or significantly improved products.

Introduced organizational innovations

Organizational innovations are new ways of organizing work and relationships with other companies and organizations that have not previously been used, and new business practices. They must be the result of decisions taken by the management of the company and should not be reported as organizational innovations or mergers and acquisitions of other companies, even if they were made for the first time.

Introduced marketing innovations

Marketing innovations are the implementation of new marketing research, marketing databases, marketing concepts and strategies that have not been used before, and are significantly different from existing enterprise marketing tools. The changes relate to the commercialization of the product design and packaging, distribution, promotion, pricing and sales.

The units in the comparative analysis are 563 small, medium and large furniture enterprises (20062008) and 358 small, medium and large furniture enterprises (2014-2016) in Bulgaria.

The common EU indicators (Eurostat questionnaire, NSI) are used, which allow comparability and for highlighting good practices in different types of innovation in the EU. They are not micro-enterprise observation units, which explains the small number of furniture enterprises reported in NSI.

The purpose of the comparative analysis is to present the innovation activity of furniture enterprises for a period before the financial crisis and a period after its passage.

Comparative analysis of the innovations of the Furniture enterprises for the periods of 20062008 and 2014-2016

The number of furniture enterprises in Bulgaria (without micro), their turnover and financial indicators related to innovations are presented in Table. 1.

Table 1 shows that there is a decrease in the number (of 205) of small, medium and large furniture enterprises after the economic crisis. There is an increase in turnover, innovation costs and revenue from innovative products. Innovation costs increased by 54875 thousand BGN and the revenues from innovative products by BGN 30046 thousand.

\begin{tabular}{|l|c|c|c|c|c|c|}
\hline \multicolumn{2}{|l|}{ Table 1: Researched furniture enterprises in Bulgaria } \\
\hline Periods & $\begin{array}{c}\text { Number of } \\
\text { Enterprises }\end{array}$ & $\begin{array}{c}\text { Turnover } \\
\text { Thousands } \\
\text { BGN }\end{array}$ & \multicolumn{2}{|c|}{$\begin{array}{c}\text { Innovation } \\
\text { Expenditures }\end{array}$} & $\begin{array}{c}\text { Revenues of the } \\
\text { innovation products }\end{array}$ \\
\hline & & & & $\begin{array}{c}\text { Thousands } \\
\text { BGN }\end{array}$ & $\begin{array}{c}\text { Thousands } \\
\text { BGN }\end{array}$ \\
\hline $2006-2008$ & 563 & 875009 & $1.3 \%$ & 11551 & $9.7 \%$ & 84935 \\
\hline $2014-2016$ & 358 & 929884 & $1.9 \%$ & 17865 & $12.4 \%$ & 114981 \\
\hline
\end{tabular}

The number of enterprises that introduced product innovations decreased that introduced product innovations in 2014-2016, for both new products and services. For the period 2006-2008, new products are introduced to the market, while for the period 2014-2016 there is a decrease is more than $4 \%$.

\begin{tabular}{|l|c|c|}
\hline \multicolumn{3}{|c|}{ Table 2: Furniture enterprises introduced product innovations, \% } \\
\hline Periods & New or improved goods & New or improved services \\
\hline $2006-2008$ & $19.2 \%$ & $3.6 \%$ \\
\hline $2014-2016$ & $14.5 \%$ & $2.5 \%$ \\
\hline
\end{tabular}

The second largest introduced innovations after product innovations for the period 2006-2008 are process innovations in production. For the period 2014-2016, they are the leading types of innovation, while those process innovations in supply are decreasing. 


\begin{tabular}{|c|c|c|c|}
\hline Period & $\begin{array}{c}\text { New or improved } \\
\text { production methods }\end{array}$ & $\begin{array}{l}\text { New or improved } \\
\text { delivery methods }\end{array}$ & $\begin{array}{c}\text { New or improved } \\
\text { additional activities }\end{array}$ \\
\hline 2006-2008 & $18.3 \%$ & $2.1 \%$ & $3.4 \%$ \\
\hline 2014-2016 & $15.6 \%$ & $2 \%$ & $6.1 \%$ \\
\hline
\end{tabular}

The third major innovations for 2006-2008 are organizational innovations - new business practices for organizing the work. For the 2014-2016 period there was a decrease in all types of organizational innovation compared to the 2006-2008 period, which was seen as mainly decrees in the new organization methods related to the allocation of responsibilities and decision-making.

\begin{tabular}{|c|c|c|c|}
\hline Table 4: Furniture enterprises introduced organizational innovations, \% \\
\hline Period & New business practices & $\begin{array}{c}\text { New methods of work } \\
\text { organization related to } \\
\text { the allocation of } \\
\text { responsibilities and } \\
\text { decision-making }\end{array}$ & $\begin{array}{c}\text { New methods of organizing } \\
\text { relationships with other } \\
\text { enterprises and public } \\
\text { organizations }\end{array}$ \\
\hline $2006-2008$ & $10.3 \%$ & $13.9 \%$ & $5.5 \%$ \\
\hline $2014-2016$ & $7.5 \%$ & $7.5 \%$ & $3.6 \%$ \\
\hline
\end{tabular}

Source: NSI and author's own data

Marketing innovations in regard to design and packaging also reported as decreased, but all other types of marketing innovations increased for the period 2014-2016 compared to 2006-2008.

\begin{tabular}{|c|c|c|c|c|}
\hline \multicolumn{5}{|c|}{ Table 5: Furniture enterprises introduced marketing innovations, \% } \\
\hline Period & $\begin{array}{c}\text { New or improved } \\
\text { design and } \\
\text { package }\end{array}$ & $\begin{array}{c}\text { New advertising } \\
\text { methods or } \\
\text { promotion } \\
\text { techniques }\end{array}$ & $\begin{array}{c}\text { New methods of } \\
\text { product } \\
\text { placement }\end{array}$ & $\begin{array}{c}\text { New methods of } \\
\text { pricing goods and } \\
\text { services }\end{array}$ \\
\hline $2006-2008$ & $9.2 \%$ & $4.6 \%$ & $4.8 \%$ & $4.4 \%$ \\
\hline 2014-2016 & $8.4 \%$ & $8.7 \%$ & $6.1 \%$ & $8.1 \%$ \\
\hline
\end{tabular}

Relatively good is the breakdown by types of innovation activities for the period 2014-2016 compared to the period 2006-2008, especially in terms of R \& D, where the increase is by $3.5 \%$. An increase is also seen in the $\mathrm{R} \& \mathrm{D}$ indicator provided by another enterprise, innovation training, and innovation marketing activities. There is a decrease in performance of the introduction of machines, equipment and software related to innovation, acquisition of external knowledge and other innovative activities.

\begin{tabular}{|l|c|c|c|c|c|c|c|}
\hline \multicolumn{2}{|c|}{ Table 6: Furniture enterprises, with expenditures for innovations, \% } \\
\hline Period & R\&D & $\begin{array}{c}\text { R\&D from } \\
\text { other } \\
\text { enterprises }\end{array}$ & $\begin{array}{c}\text { Acquisition } \\
\text { of } \\
\text { machines, } \\
\text { equipment } \\
\text { and } \\
\text { software }\end{array}$ & $\begin{array}{c}\text { Acquisition } \\
\text { of external } \\
\text { knowledges }\end{array}$ & $\begin{array}{c}\text { Training to } \\
\text { innovations }\end{array}$ & $\begin{array}{c}\text { Marketing } \\
\text { activities to } \\
\text { present the } \\
\text { innovations }\end{array}$ & $\begin{array}{c}\text { Other } \\
\text { innovation } \\
\text { activities }\end{array}$ \\
\hline $\begin{array}{l}2006- \\
2008\end{array}$ & $1.5 \%$ & $0.7 \%$ & $22.7 \%$ & $3.6 \%$ & $7.1 \%$ & $7.3 \%$ & $7.5 \%$ \\
\hline $\begin{array}{l}2014- \\
2016\end{array}$ & $5 \%$ & $1.4 \%$ & $18.2 \%$ & $3.1 \%$ & $8.1 \%$ & $7.5 \%$ & $7.3 \%$ \\
\hline
\end{tabular}

There is an increase in the financing of innovations from the EU by more than $11 \%$ for the period 2014-2016, which can be explained by increased EU opportunities from different types of projects and programs that fund innovation. The lack of results on the indicator "institutions of local government and government institutions" show that they are the units of enterprises with activity (:c). 


\begin{tabular}{|l|l|l|l|}
\hline \multicolumn{2}{|c|}{ Table 7: Furniture enterprises, with financing of innovations from EU, \% } \\
\hline Period & $\begin{array}{c}\text { From local government } \\
\text { institutions }\end{array}$ & $\begin{array}{c}\text { From government } \\
\text { institutions }\end{array}$ & \multicolumn{1}{|c|}{ From EU } \\
\hline $2006-2008$ & $2.7 \%$ & $\mathrm{c}$ & $0.5 \%$ \\
\hline $2014-2016$ & $\mathrm{c}$ & $10.3 \%$ & $12.3 \%$ \\
\hline
\end{tabular}

Source: NSI and author's own data

\section{Conclusions}

The results of the survey of the innovation activity of the furniture enterprises in the two different periods shows that for the 2006-2008 period the main innovations are the introduction of new products and for 2014-2016 the introduction of new processes and production methods.

2006-2008

1) Product innovations - new or improved products

2) Process Innovations - new or improved production methods

3) Organizational Innovations - New Methods of Organization of Work Related to the Allocation of Responsibilities and Decision Making

4) Organizational Innovations - New Business Practices for Workflow Organization

5) Marketing Innovations - New Design and Packaging

6) Organizational Innovations - New Methods of Organizing Relationships with Other Enterprises or Organizations

7) Marketing innovations - new methods of product placement

8) Marketing Innovations - New Advertising Methods and Promotion Techniques

9) Marketing Innovations - New Pricing Methods

10) Product innovations - new or improved services

2014-2016

1) Process Innovations - new or improved production methods

2) Product innovations - new or improved products

3) Marketing Innovations - New Advertising Methods and Promotion Techniques

4) Marketing Innovations - New Pricing Methods

5) Marketing Innovations - New Design and Packaging

6) Organizational Innovations - New Business Practices for Workflow Organization

7) Marketing innovations - new methods of product placement

8) Organizational Innovations - New Methods of Organizing Relationships with Other Enterprises or Organizations

9) Product innovations - new or improved services

10) Organizational innovations - new or improved delivery methods

The comparative analysis of the innovation activity of the furniture enterprises in Bulgaria - before and after the period of the economic crisis, shows that the furniture enterprises do the same innovation activities - for both periods under review the leading innovation activity is the acquisition of machinery, equipment and software related to innovation, and the same lowest results - R \& D provided by another enterprise.

The innovative activities of the enterprises for the two periods are arranged in the following order: 2006-2008

- Acquisition of machinery, equipment and software related to innovation

- Other innovative activities

- Marketing activities for innovation performance

- Training for innovations

- Acquisition of other external knowledge

- $\mathrm{R} \& \mathrm{D}$

- $\mathrm{R} \& \mathrm{D}$ provided by another enterprise 
2014-2016

- Acquisition of machinery, equipment and software related to innovation

- Training for innovations

- Marketing activities for innovation performance

- Other innovative activities

- $\mathrm{R} \& \mathrm{D}$

- Acquisition of other external knowledge

- $\mathrm{R} \& \mathrm{D}$ provided by another enterprise

The main conclusions of the comparative analyses of the innovation activity of the furniture enterprises in Bulgaria for the two periods under review shows the increasing and decreasing of different indicators. It is shows the increasing of: the innovation expenditures and revenues from innovative products; the process innovations - additional activities; the financing of innovation activities by the EU. It is shows the decreasing of: the number of furniture enterprises; product innovations; process innovations related to production and delivery; organizational innovations.

\section{Acknowledgements}

This document was supported by the grant No BG05M2OP001-2.009-0034-C01 "Support for the Development of Scientific Capacity in the University of Forestry", financed by the Science and Education for Smart Growth Operational Program (2014-2020) and co-financed by the European Union through the European structural and investment funds.

\section{References}

Chobanova R., L. Kocarev, R. Popova, D. Georgieva, Z. Trayanov, D. Traychevska, R. Angelova (2018) Forestry sector in Bulgaria and Macedonia, Economic Research Institute of the Bulgarian Academy of Sciencies, ISBN 978-954-931, p. 30-47.

Gault, F. (2018) "Defining and measuring innovation in all sectors of the economy", Research Policy, Vol. 47/3, pp. 617-622. Industry, Trade and Services Report (2018) http://appsso.eurostat.ec.europa.eu/nui/show.do?dataset=sts_intv_m\&lang=en

Innovation activity during the period 2014 - 2016 Paper (2018)

http://www.nsi.bg/sites/default/files/files/pressreleases/NIRD_Innovation2016_en_FB3CA2F.pdf

OECD (2005) "The Measurement of Scientific and Technological Activities: Guidelines for Collecting and Interpreting Innovation Data: Oslo Manual, Third Edition" prepared by the Working Party of National Experts on Scientific and Technology Indicators, OECD, Paris, para. 149.

OECD/Eurostat (2018), Oslo Manual 2018: Guidelines for Collecting, Reporting and Using Data on Innovation, 4th Edition, The Measurement of Scientific, Technological and Innovation Activities, OECD

Publishing, Paris/Eurostat, Luxembourg.

OECD (2015a), "Making open science a reality”, OECD Science, Technology and Industry Policy Papers, No. 25, OECD Publishing, Paris, https://doi.org/10.1787/5jrs2f963zs1-en.

OECD (2015b), Frascati Manual 2015: Guidelines for Collecting and Reporting Data on Research and Experimental Development, The Measurement of Scientific, Technological and Innovation Activities, OECD Publishing, Paris, http://oe.cd/frascati.

Petrov, M., M. Slavova (2006) Innovation Policy and International Business, Economy IM, Sofia.

Popova R. (2013) Innovation in Forest Industry, Intel Entrans, 173.

Raymond A.G \& Company Inc. (2009) Creating a Furniture Factory for The Future, Management and Technical Solutions for the Wood Products Industry, American Home Furnishings Alliance,U.S.A., 44.

Report on the state of the EU woodworking sector for 2017/2018 (2018 ) https://timberchamber.com/exportportal_pages/446 Taneva, N. (2006) Innovation Management, Sofia.

World Furniture Review Report 2018/2019 (2018) https://timberchamber.com/exportportal_pages/453 